\title{
Trabalhadores Urbanos, Estudantes e Guerrilheiros escrevem a História a Contrapelo na Sociedade Brasileira de 1968
}

\author{
Urban workers, students, and guerrillas write history against the grain in \\ the Brazilian society of 1968
} Trabajadores Urbanos, Estudiantes y Guerrilleros escriben la Historia a
contrapelo en la Sociedad Brasileña de 1968

\author{
Carlos Bauer ${ }^{1}$ \\ Universidade Nove de Julho (Brasil) \\ Grupo de pesquisa HISULA - UPTC
}

Recepción: 20/05/2017

Evaluación: 08/09/2017

Aceptación: 05/01/2018

Artículo de investigación - Reflexión

DOI: https://doi.org/10.19053/01227238.8015

\section{RESUMO}

Neste ensaio se analisa a presença dos estudantes, operários e guerrilheiros em alguns episódios políticos registrados a partir de 1968 no Brasil, partindo-se de uma reflexão sobre a estreita relação que esses personagens sociais mantiveram com a luta armada e a da importância da herança política e organizativa que propiciaram aos movimentos sociais que irromperam desde a segunda metade da década de 1970. A presença desses movimentos armados e o seu caráter pedagógico como parte indissolúvel da história dos movimentos sociais permite entendê-los como aqueles que tomam uma direção inesperada, contrária à edificação da ordem e dos mecanismos de dominação que são próprios da sociedade capitalista; mas que ousam virar o mundo de ponta cabeça e semear no solo fértil da história a utopia de uma sociedade sem explorados, nem exploradores.

Palavras-chave: movimentos sociais; luta armada; história dos movimentos sociai; década de 1960; movimentos sociais e resistência ao regime militar.

1 Carlos Bauer é professor do Programa de Pós-Graduação em Educação (PPGE), da Universidade Nove de Julho (Uninove) e autor, entre outros, dos livros História e internacionalismo da Escola Nacional Florestan Fernandes, Introdução crítica ao humanismo dialógico de Paulo Freire e A classe operária vai ao campus. Esboço de história social, trabalho precário, resistência e ousadia na universidade brasileira contemporânea (publicados pela Editora Sundermann, in: www.editorasundermann.com.br). Correo eletrônico: professorcarlosbauer@cnpq.pesquisador.br 


\begin{abstract}
This article analyzes the presence of students, workers, and guerrillas in some political episodes documented since 1968 in Brazil. Based on a reflection about the close relationship of these social characters with the armed struggle and the importance of the political and organizational inheritance that fostered the social movements from the second half of the 1970s. The presence of these armed movements and their pedagogical nature, as an indivisible part of the history of social movements, allows us to understand them as agents of unexpected changes, contrary to the settlement of order and the mechanisms of domination, typical characteristics of a capitalist society. These movements dare to turn the world from head to toe and sow, in the fertile soil of history, the utopia of a society neither exploited nor with exploiters.

Keywords: social movements; armed struggle; history of social movements; 1960 s, social movements; resistance to the military regime.
\end{abstract}

\section{RESUMEN}

En este ensayo se analiza la presencia de los estudiantes, obreros y guerrilleros en algunos episodios políticos registrados a partir de 1968 en Brasil, partiendo de una reflexión sobre la estrecha relación que estos personajes sociales mantuvieron con la lucha armada y la de la importancia de la herencia política y organizativa que propiciaron a los movimientos sociales que irrumpieron desde la segunda mitad de la década de 1970. La presencia de esos movimientos armados y su carácter pedagógico como parte indisoluble de la historia de los movimientos sociales permite entenderlos como aquellos que toman una dirección inesperada contraria a la edificación del orden y de los mecanismos de dominación que son propios de la sociedad capitalista; pero que se atreven a girar el mundo de punta cabeza y sembrar en el suelo fértil de la historia la utopía de una sociedad sin explotar, ni exploradores.

Palabras clave: movimientos sociales; lucha armada, historia de los movimientos sociales; la década de 1960, movimientos sociales; resistencia al régimen militar.

\section{INTRODUÇÃO}

O intuito desse ensaio de interpretação histórica é verificar alguns acontecimentos que se produziram no Brasil em 1968 e as suas repercussões políticas e sociais. Partimos do pressuposto de que muitos desses episódios marcaram a história brasileira contemporânea na sua inteireza, mas, ao procurarmos resgatar sua memória objetivamos refletir sobre suas repercussões na esfera dos movimentos sociais e o papel pedagógico que teriam, ou, não, desempenhando em sua urdidura e desenvolvimento.

Aproximadamente 50 anos depois vivemos uma aparente anestesia dos movimentos sociais e o auge de um ciclo conservador oposto pelo vértice daquele instante que se prometia como a primavera dos povos e a possibilidade das utopias e sonhos de mudanças radicais se realizassem em todo o mundo.

Em muitos países do mundo, 1968 trouxe a possibilidade histórica da ruptura com os valores e mecanismos da reprodução social próprios do capitalismo e os seus reflexos transcenderam as fronteiras nacionais e simultaneamente atingiram aos mais variados países. Na Europa, nos Estados Unidos, na América 
Latina e no Brasil também os conflitos tornaram-se visíveis nas manifestações do movimento negro, nos protestos contra a Guerra do Vietnã, contra a presença soviética do leste Europeu; como também contra as inúmeras ditaduras militares que varriam os países latino-americanos, além de um sem número de fenômenos políticos, culturais e sociais que continuam ecoando até hoje em nossas vidas.

Em 1968, nos Estados Unidos da América, são assassinados Martin Luther King e Robert Kennedy, as contradições explodiam embaladas pelos protestos negros e contra a Guerra do Vietnã, mas o conservadorismo político se consolidou naquele país que hoje detém o maior e insuperável número de armas registradas por habitantes e, assim, na prática, manifestam uma predileção pela violência sem comparação no mundo.

Num outro contexto, dimensionando a importância histórica da Comuna de Paris Karl Marx escreveu "há dias que valem por séculos na história dos povos", assim, parafraseando esse autor podemos dizer também que existem anos que marcam profundamente a história, esse é o caso de 1968.

Naqueles dias, no Brasil, muitas organizações políticas, operárias e estudantis de esquerda que haviam rompido com o Partido Comunista Brasileiro (PCB), com a vida institucional, por conta das cassações, perseguições do Estado ou mesmo pelo afastamento de algumas correntes mais radicais do pensamento católico, como é caso da Ação Popular (AP), optaram pela luta armada contra a ditadura civil-militar instalada no país. Opção essa que trouxe à morte trágica, o desaparecimento, a prisão arbitrária e a tortura para muitos que ousaram enfrentar a sanha autoritária da ditadura militar, então, vigente no país ${ }^{2}$.

Em 1968 tivemos nas cidades de Osasco (SP) e de Contagem (MG) a emergência de um novo sindicalismo, fortemente implantando nas comissões de fábricas, rompendo, na prática, com o Sindicato de Estado vigente, com uma capacidade de mobilização política e autonomia da classe operária, até então inusitado, e oposto pelo vértice do sindicalismo servil e disciplinado que havia se constituído durante o Governo de Getúlio Vargas (1930-1945).

2 Para uma compreensão mais ampliada e documentada desse processo histórico consultar, especialmente, o livro, de nossa autoria. Carlos Bauer, Contribuição para a história dos trabalhadores no Brasil. Volume II. A hegemonia vermelha. (São Paulo: Edições Pulsar, 1995), 282. 


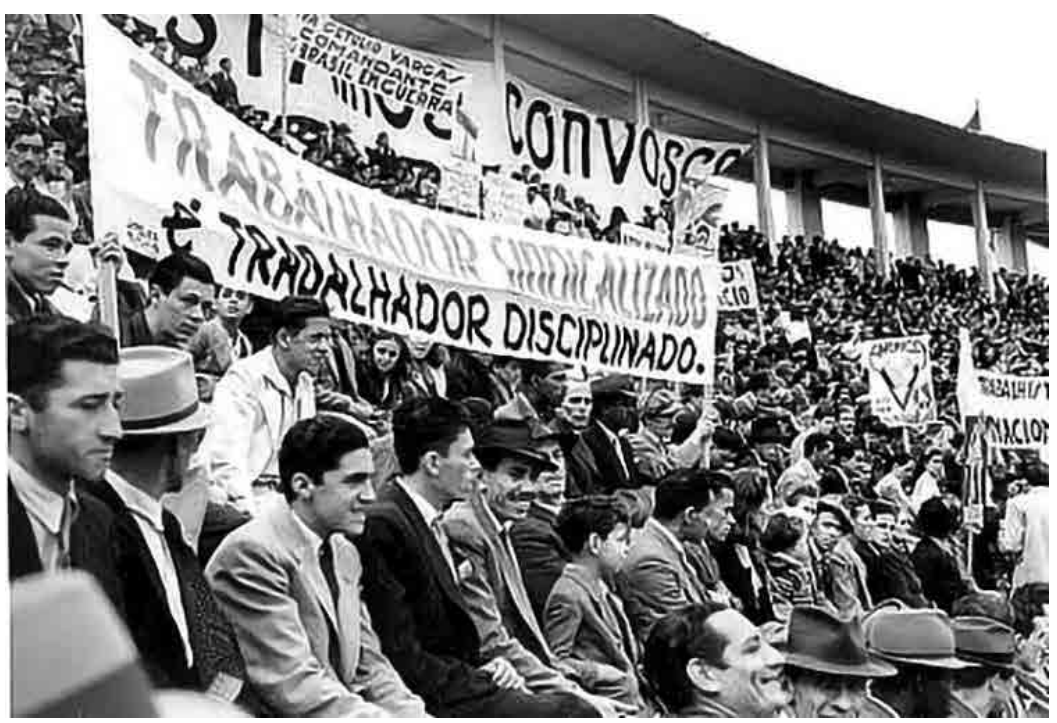

Figura 1: Manifestação cívica varguista do dia 01 de maio de 1941.

FONTE: Acervo do autor.

Não é nenhum exagero se afirmar que esse tipo de organização da classe trabalhadora é crucial para se entender a gênese da Central Única dos Trabalhadores (CUT) e do Partido dos Trabalhadores (PT) que hoje assumem um papel destacado no cenário político e sindical nacional. Também importantes setores da Igreja Católica passaram para a oposição ao regime militar, como os partidos políticos, as organizações estudantis, operárias, camponesas e mesmo muitos intelectuais estavam proscritos, passaram dar voz aos perseguidos políticos, aos trabalhadores explorados, aos injustiçados que a ditadura produzia todos os dias. Suas críticas, contudo, iam muito além dos episódios que se produziam no Brasil e questionavam o próprio capitalismo e a sua essência de exploração. Suas críticas e diagnósticos sociais, reflexões políticas e filosóficas são a base do que convencionamos chamar de Teologia da Libertação.

Praticamente 50 anos depois é possível indagar: se produziu um tempo necessário para possibilitar uma reflexão crítica sobre os acontecimentos e as repercussões políticas e sociais daquele ano que para muitos iria mudar o mundo e o Brasil?

\section{Dos guerrilheiros, suas organizações e formas de compreender a realidade brasileira.}

Foi a partir de 1968 que um sem número de organizações de esquerda que havia rompido com a linha pacifista do Partido Comunista Brasileiro (PCB) ou mesmo algumas correntes mais radicais do pensamento católico como é o caso na Ação Popular (AP) optaram pela luta armada. Mas, antes disso, os estudantes assumiram um lugar central entre os que se opunham ao regime autoritário. 
Questionando a interferência estrangeira na educação, na economia e nos rumos da vida pátria, protestavam nas ruas contra o famigerado Acordo MEC-USAID, o questionamento da presença imperialista no país, materializada na política do FMI e o descompromisso entreguista de alguns setores das elites nacionais. Logo, não se constituiu por acaso que muitos militantes do movimento estudantil assumiriam um papel destacado na opção de luta armada contra a ditadura civil-militar que havia tomado de assalto o poder em 1964.

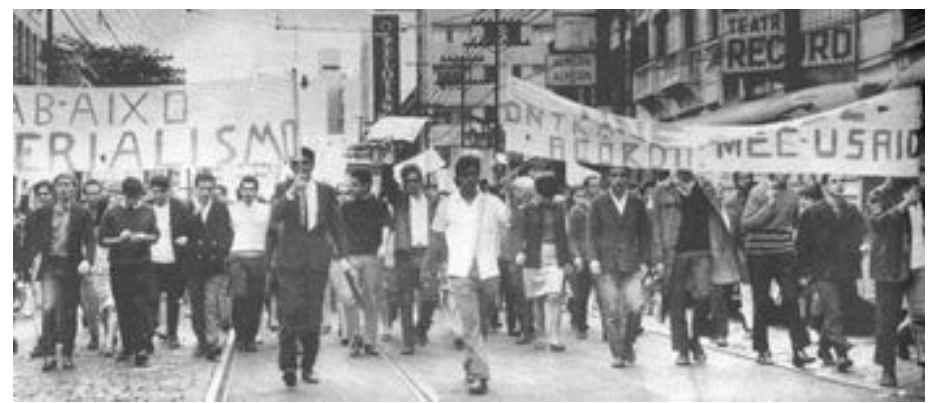

Figura 2: Manifestação dos estudantes contra o imperialismo e os acordos MEC-USAID em 1968.

FONTE: Acervo do autor.

Nos primórdios da década de 1960, a universidade no Brasil era considerada um território livre e os debates que se produziam nos campi reivindicavam a revolução e a própria questão da liberdade e autonomia universitária articulavase com os projetos da nova sociedade que se buscava alcançar. Alimentado, assim, os sonhos de toda uma geração de estudantes que parecia disposta a mudar o mundo com as suas próprias mãos!

Entre esses jovens estava o estudante secundarista Edson Luís Lima Souto. Morto em pleno restaurante universitário do Calabouço, no Rio de Janeiro, transformou-se num marco de profunda indignação e consternação em todo país. O seu trucidamento desnudava o caráter arbitrário, a violência de Estado patrocinada pelo regime militar e a efetivação dos mecanismos coercitivos de controle social principalmente tornados visíveis com a edição dos Atos Institucionais (AI), entre eles o AI-5, em 13 de dezembro de 1968. 


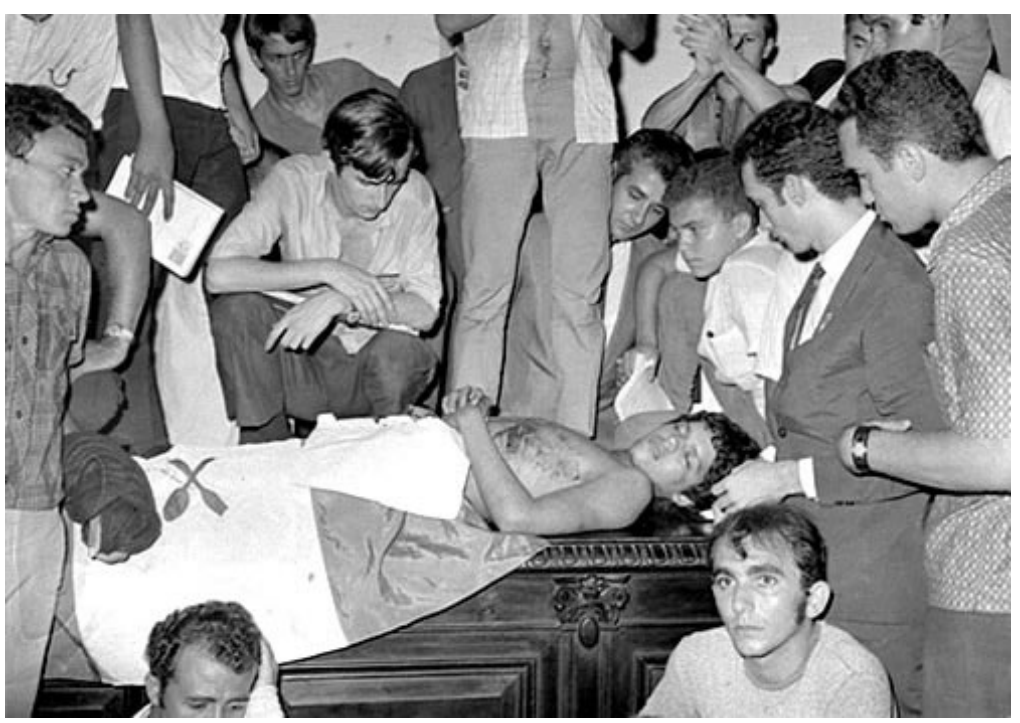

Figura 3: Corpo do estudante Edson Luis assassinado no restaurante universitário do Calabouço em 1968.

FONTE: Acervo do autor.

A indignação social causada pelo assassinato de Edson Luís, com um tiro no coração, desferido pelo revólver do também jovem aspirante da PM Aloísio Raposo, espalhou-se rapidamente e levou uma multidão ao seu velório que foi realizado na Assembleia Legislativa do Estado do Rio de Janeiro. Os desdobramentos desse funeral podem ser considerados uma das primeiras manifestações massivas contra o regime militar e sua prática repressiva e cerceamento das liberdades civis.

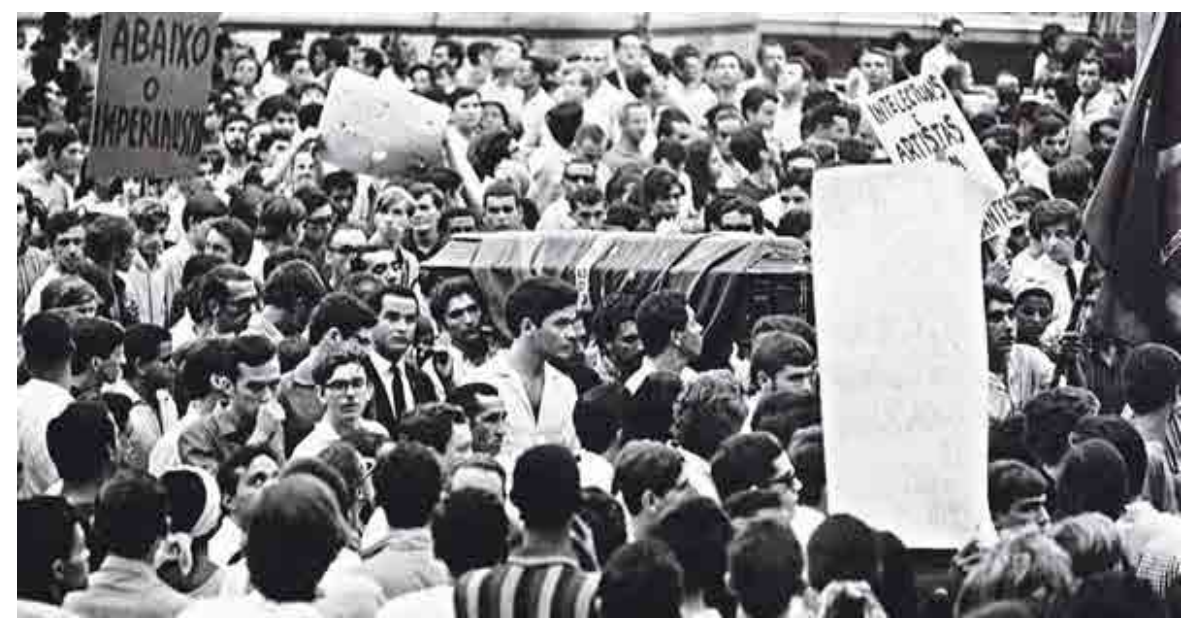

Figura 4: Cortejo fúnebre do estudante Edson Luis assassinado no restaurante universitário do Calabouço em 1968.

FONTE: Acervo do autor. 
Iniciava-se, assim, um curto ciclo de manifestações pacíficas contra a ditadura militar e, logo depois, se produziu uma das maiores manifestações realizadas, até então, contra a escalada de violência que atingia os partidos políticos, a imprensa, os intelectuais e outros representantes da sociedade civil: a Passeata dos Cem mil.

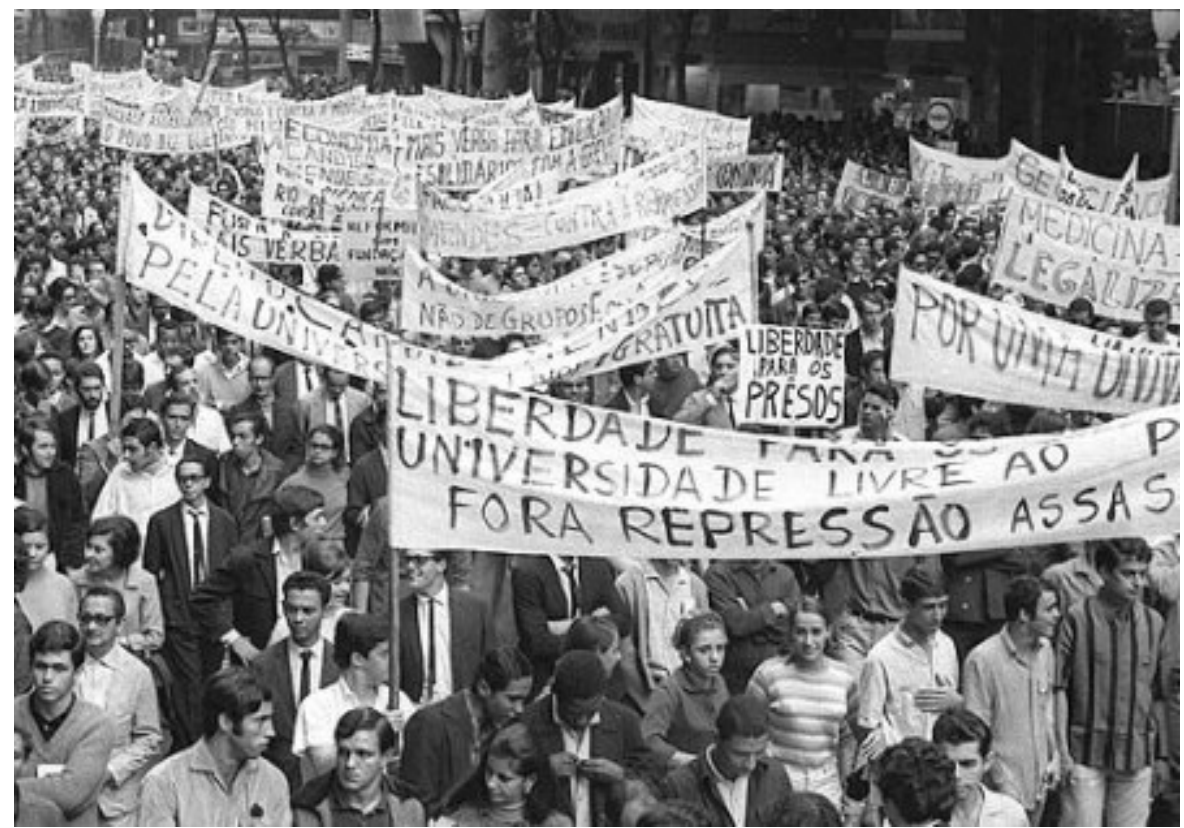

Figura 5: Manifestação pública pacífica contra o assassinato do estudante Edson Luis em 1968.

FONTE: Acervo do autor.

A busca de uma saída pacífica para crise política e que evitasse o confronto mostrou-se infrutífera, pois apenas sete dias depois do cortejo fúnebre de Edson Luís, em plena escadaria da Igreja da Candelária, os cavalarianos da Polícia Militar desciam o porrete nas costas dos que haviam acabado de participar da missa em memória do estudante morto. 


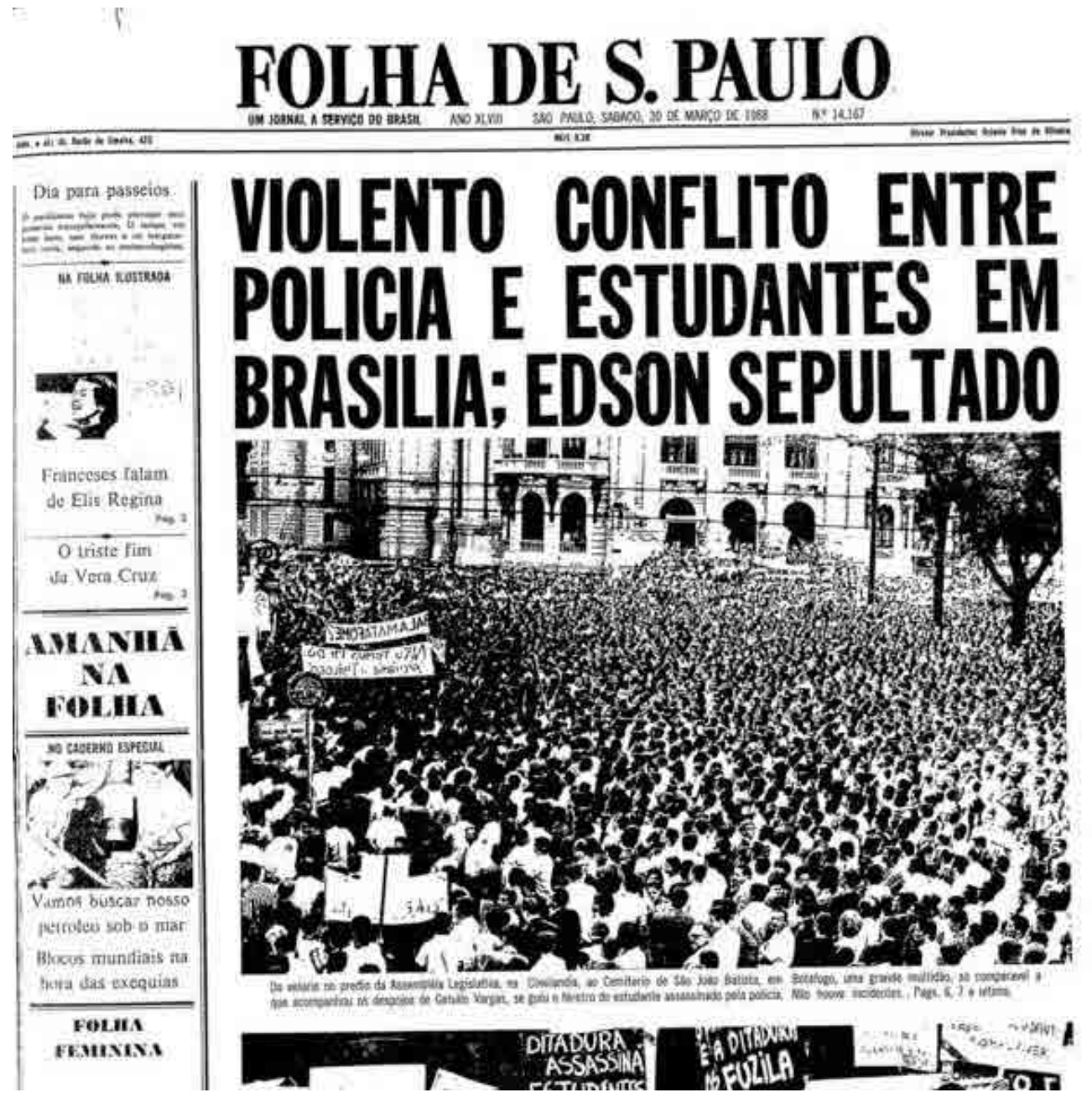

Figura 6: Manchete do jornal Folha de São Paulo, relatando os conflitos entre estudantes e policiais por ocasião do sepultamento do estudante Edson Luís.

FONTE: Folha de S. Paulo, p. 1, 30 de março de 1968; Acervo do autor.

A partir daí verificou-se a escalada da violência policial e militar pelas ruas de todo país, a opção pela guerrilha urbana e o desfecho que o AI-5 produziu, ou seja, a implantação de uma ditadura total, não foi mera coincidência. Ademais, diante da inviabilidade do regime militar suportar uma democratização estrutural do Estado, o que não permitiria levar adiante os seus projetos econômicos de integrar o Brasil nos cânones da economia transnacional e do capitalismo internacional. Enfim, para os arautos do regime militar, como o ministro da Justiça, Gama e Silva, não havia saída dentro da ordem.

A perspectiva da guerrilha enquanto concepção de enfrentamento armado contra a ditadura militar foi adotada por um sem número de agrupamentos políticos que atuando na clandestinidade realizaram ações armadas em 
diferentes regiões e estados do país. Entre esses grupos, se notabilizaram a Ação Libertadora Nacional (ALN), comandada pelo ex-deputado federal e exmembro da direção executiva do Partido Comunista Brasileiro (PCB), Carlos Marighella, e a Vanguarda Popular Revolucionária (VPR), liderada pelo excapitão do Exército Brasileiro Carlos Lamarca.

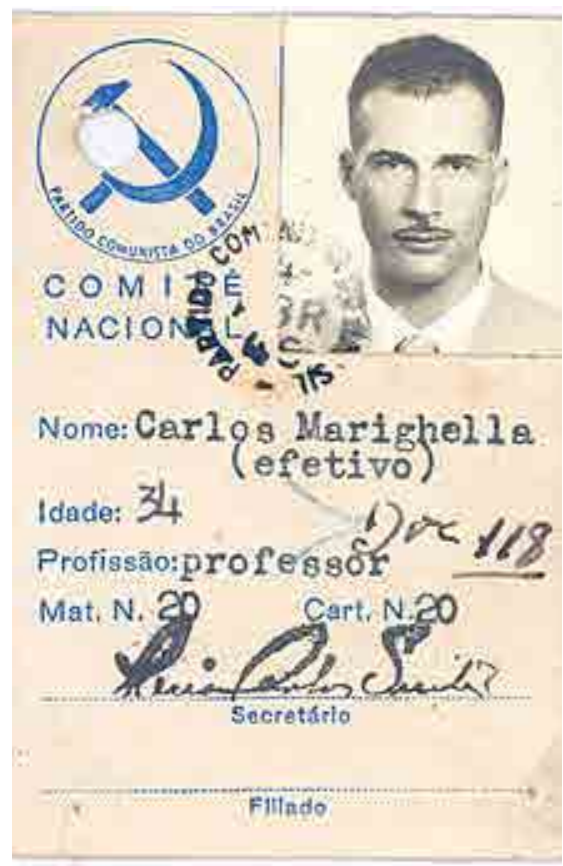

Figura 7: Registro da filiação política de Carlos Marighela ao PCB.

FONTE: Acervo do autor

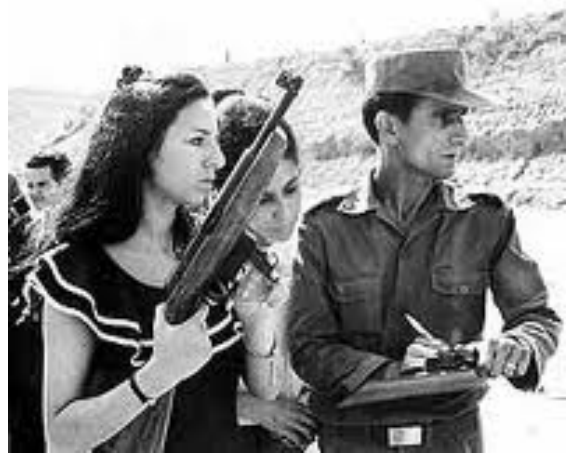

Figura 8: Registro fotográfico de Carlos Lamarca, ainda como membro do Exército brasileiro, oferecendo treinamento de tiro aos funcionários do Banco Brasileiro de Descontos (Bradesco).

FONTE: Acervo do autor 
Outro agrupamento formado com militantes políticos vinculados ao Partido Comunista do Brasil (PC do B), partindo de uma concepção maoista de instalação de focos de intervenção política no meio rural, organizou no início da década de 1970 um movimento guerrilheiro no sul do Pará. Instalados numa inóspita região do Araguaia, contando com um incipiente apoio da população local, algumas dezenas de guerrilheiros, vinculados ao partido, estabeleceram o que o general Hugo Abreu, comandante das tropas enviadas para sufocar o movimento revolucionário, classificou como "o mais importante movimento armado já ocorrido no Brasil rural".

Exageros à parte! Mas que muitas vezes foram utilizados para se justificar o extermínio dos membros desses grupos, durante o Governo do General Médici (1969-1974) e, em menor intensidade, no Governo Geisel (1974-1979), os agrupamentos identificados com a luta armada no campo e na cidade foram sendo localizados, perseguidos e eliminados, com a utilização de uma enorme mobilização de tropas e do aparelho repressivo do Estado. 


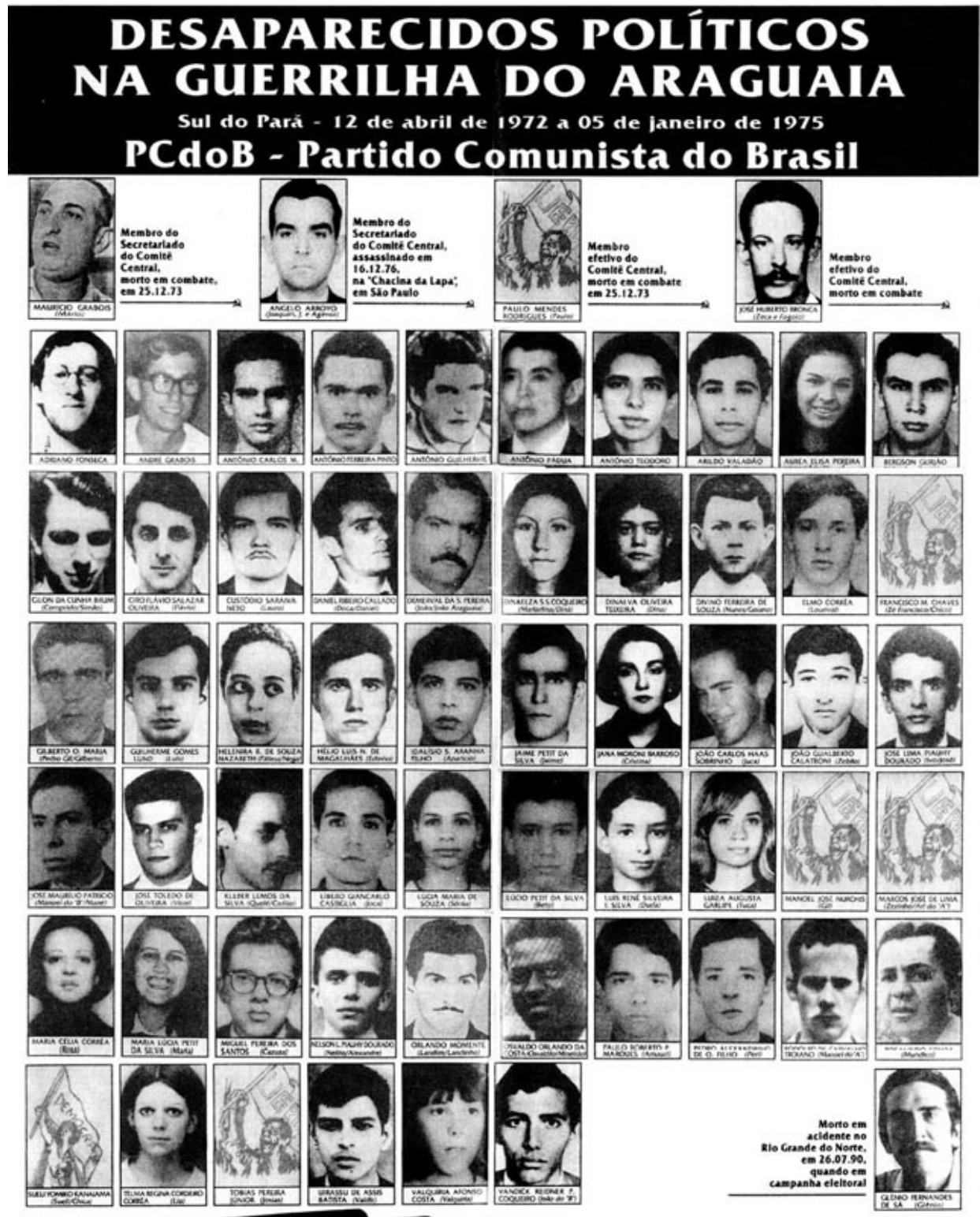
Morreram lutando por Liberdade e Democracia

Figura 9: Cartaz com as fotografias dos desaparecidos políticos na Guerrilha do Araguaia, de 12 de abril de 1972 a 05 de janeiro de 1975.

FONTE: Acervo do autor 
No sul do Pará, as forças repressivas mobilizaram um impressionante contingente militar envolvendo, aproximadamente, vinte mil soldados para debelarem a aventura guerrilheira de algumas dezenas dos militantes do PC do B. O resultado desta ofensiva foi o assassinato de pelo menos 61 militantes das forças guerrilheiras que atuavam no Araguaia. Entretanto, a repressão desencadeada contra os grupos que optaram pela oposição armada ao regime militar acabou, também, atingindo um sem número de pessoas que não estavam envolvidas diretamente com a luta armada, muitas das quais, além de presas de forma violenta e arbitrária, foram torturadas, mortas e enterradas em sepulturas clandestinas.

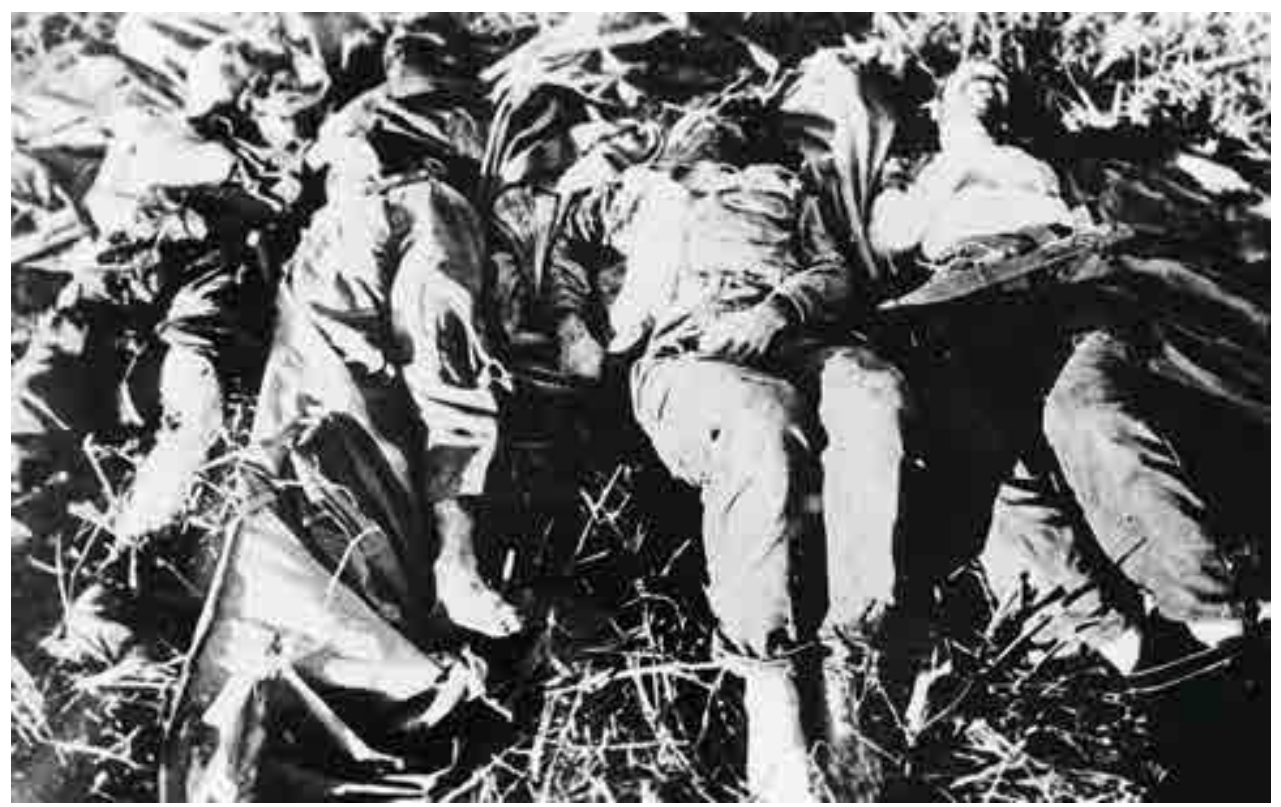

Figura 10: Fotografia dos guerrilheiros aprisionados, martirizados e mortos na Guerrilha do Araguaia, de 12 de abril de 1972 a 05 de janeiro de 1975. FONTE: Acervo do autor

Aliás, na luta contra as hostes repressivas do Estado militarizado foram mortas mais de uma centena de pessoas e outras tantas são contadas como desaparecidas. Desaparecido é um eufemismo que se utiliza para se falar de alguns brasileiros que foram perseguidos, presos e trucidados ilegalmente pelo regime militar, e que não tem, nem mesmo, o direito a uma sepultura digna e sobre a sua própria morte!

Também os acontecimentos do Primeiro de Maio de 1968, momento no qual alguns setores organizados do movimento operário e estudantes ligados aos grupos de esquerda expulsaram o governador e incendiaram o palanque instalado na Praça da Sé, as greves operárias em Osasco e Contagem e seus desdobramentos políticos refletiam uma perspectiva foquista de luta revolucionária. Uma concepção que apostava na irradiação da luta revolucionária, 
que iria assim contagiando diferentes setores da sociedade, após sua instalação em pontos "estratégicos" do país. Mas essa caracterização não era exclusiva dessa ou daquela organização, elas formavam o pano de fundo das análises elaboradas pela quase totalidade das organizações de esquerda que optou pela luta armada contra o regime e que constituíram durante as décadas de 1960 e 1970 uma verdadeira constelação de agrupamentos adeptos dessa tática de atuação política.

\section{As raízes dos movimentos de Osasco e Contagem}

Os protestos contra os baixos níveis salariais e contra a política de contenção das liberdades democráticas fizeram emergir as greves de Osasco e Contagem e as haveriam de transformar em "símbolos" da luta contra a ditadura militar. As raízes desses movimentos podem ser buscadas ainda em 1965 quando prosperou nas periferias de São Paulo e Belo Horizonte, grupos de base e estudantes universitários que então realizavam um intenso trabalho de agitação social e propaganda política em torno das péssimas condições de trabalho, arrocho dos salários e do alto custo de vida.

Em 1967, grupos de militantes sindicais formaram comissões de "oposição sindical", encarregadas de atuar nos sindicatos para recuperar os cargos eletivos ocupados por interventores mandatários do governo ditatorial. Realizaram-se regularmente campanhas eleitorais para dotar as estruturas corporativas de alguma flexibilidade e legitimidade. A oposição ocupou com estas campanhas o limitado espaço disponível mobilizando os trabalhadores e valendo-se da oportunidade para elevar o nível de consciência dos problemas sociais e econômicos que afetavam seus salários e suas vidas.

As contradições da política de "renovação sindical" tornaram-se manifestas nas eleições realizadas em 1967, no Sindicato dos Metalúrgicos de Contagem, cidade operária localizada nos arredores de Belo Horizonte, exatamente porque as oposições sindicais, que era baseada na representação dos trabalhadores que atuavam no interior das fábricas, organizaram uma chapa para concorrer com os titulares oficiais.

O programa da oposição continha uma análise da democratização interna da estrutura sindical, e preconizava claramente a direta participação dos trabalhadores na administração do sindicato. Também criticava a política de contenção salarial do governo e a instituição do Fundo de garantia por tempo de serviço (FGTS) em detrimento da estabilidade no emprego arduamente conquistada pelos trabalhadores.

Na cidade paulista de Osasco a maioria dos grupos de base que atuavam no movimento sindical era ligada às pastorais operárias, ou às organizações políticas de esquerda que estavam próximas aos movimentos estudantis e de massa. Isto queria dizer politicamente que as maiorias desses militantes estavam presentes nos bairros e nas fábricas e frequentavam as assembleias sem levar em 
consideração à linha sindical do governo, aplicada fielmente pelos dirigentes sindicais da época.

Dessa sorte, no campo oposicionista o que se podia verificar eram esboços de uma orientação política que apontava para o rompimento com a tradição clientelista, buscando assumir uma postura de rebeldia frente ao Ministério do Trabalho e aos dirigentes sindicais "oficiais" que sempre procuravam conciliar os interesses dos operários com os dos governos e do patronato.

Embora existissem semelhanças nos movimentos deflagrados pelos trabalhadores metalúrgicos de Osasco e Contagem, o contexto político e sindical também tinha suas diferenças. ${ }^{3}$

A violenta greve que irrompeu em Osasco no ano de 1968, pode ser compreendida como um produto da ruptura ideológica e organizativa com as concepções do sindicalismo de Estado, pois sua origem e desenvolvimento buscavam se estruturar através de um incansável trabalho de organização molecular e de permanente politização dos setores de base; que se colocavam em oposição direta à política salarial vigente do governo militar.

Criticavam também as concepções corporativistas do sindicato, seu caráter verticalizado e o contumaz atrelamento ao Estado e sua política de controle social, o que levou os dirigentes sindicais de Osasco, naqueles dias, a se afastarem tanto das propostas "conciliadoras" emanadas do MIA, quanto de quaisquer perspectivas de se associarem aos partidários daqueles que preconizavam a necessidade de se constituir uma frente ampla e democrática para se combater os militares.

Para os metalúrgicos de Osasco não se tratava apenas de conquistar melhores aumentos na época do dissídio, também "existia, (...), uma questão política":

[...] nossa visão naquela época. Estávamos ligados ao movimento de massas, mas bastante comprometidos com as posições de uma ruptura com o reformismo e de luta armada que a esquerda começava a levantar. Partíamos da mesma análise de conjuntura que o restante da esquerda estava fazendo: o governo está em crise, ele não tem saída, o problema é aguçar o conflito, transformar a crise política em crise militar. Daí vinha nossa concepção insurrecionalista de greve: levar a massa, através de uma radicalização crescente, a um confronto com as forças de repressão. Era a visão militarista aplicada ao movimento de massas. Correspondia a uma determinada concepção do processo revolucionário ${ }^{4}$.

Osasco e Contagem como experiências de "um novo sindicalismo" apontavam uma tentativa de ruptura com a tradição de controle burocrático e de manipulação política muito presente na história do movimento sindical brasileiro e até então vigentes. E demonstravam também que a luta política dos

3 Para o detalhamento dessa questão, conferir o trabalho de Francisco C. Weffort, Participação e conflito industrial: Contagem e Osasco - 1968 (São Paulo: Cebrap, caderno 5, 1972).

4 José Ibrahim y José Campos Barreto. “Manifesto de balanço da greve de julho" em A esquerda e o movimento operário: 1964/1984. Volume I. A resistência à resistência: 1964/197, eds. Celso Frederico (São Paulo: Novos Rumos, 1987), 37. 
trabalhadores deveria exigir um trabalho cotidiano de base a partir dos locais de trabalho. A grande inovação das greves de 1968 está associada ao fato de terem sido realizadas sem a ação de piquetes, iniciando-se dentro da própria fábrica, em horário de expediente.

Outra novidade, criada pelos metalúrgicos de Contagem, mas levada a extremos pelos de Osasco, foi à ocupação e o controle da própria fábrica, com os operários assumindo os postos estratégicos da empresa, passando a dirigi-los, o que trouxe significativa mobilização proletária na execução dessa inusitada empreitada política.

A reivindicação dos operários de Contagem e que se constituiu logo no primeiro dia do movimento, e depois encampada pelos operários de outras fábricas, era a outorga de $25 \%$ de aumento salarial. O Ministro do Trabalho, coronel Jarbas Passarinho, foi chamado às pressas e voou para Minas Gerais com o intuito negociar com os grevistas. De forma ardilosa o presidente do Sindicato negou que a entidade tivesse promovido ou mesmo dirigisse a paralisação (mesmo porque poderia sofrer intervenção da DRT em caso contrário), mas se solidarizava com os grevistas e chegou mesmo a oferecer o auditório do Sindicato para as negociações.

No final de abril, o General presidente Costa e Silva acabou assinado um decreto de emergência, concedendo $10 \%$ de abono salarial, quantia que deveria ser compensada no dissídio de novembro. O resultado não agradou aos operários, nem à maior parte das organizações políticas, mas acabou representando uma vitória efetiva dos metalúrgicos mineiros (que prometiam voltar à greve para integralizar o aumento). Até o dia primeiro de maio, a maioria dos trabalhadores continuou em greve. ${ }^{5}$

A greve de Osasco refletiu uma longa experiência de organização política e sindical, a partir dos locais de trabalho, envolvendo militantes da Frente Nacional do Trabalho (FNT), um agrupamento de advogados trabalhistas e operários cristãos, que se apresentavam publicamente como opositores da direção do sindicato por este, então, serem pretensamente dirigidos por comunistas. Além do que se propunham também a efetivar um trabalho de denúncias das degradantes condições laborais e de conscientização política a partir dos próprios locais de trabalho.

Nas greves anteriores, os metalúrgicos da Cobrasma já haviam tido uma participação destacada. Em outra destacada fábrica da região, a Braseixos, os operários começaram a se afastar da orientação política do PCB e de suas concepções sindicais por eles caracterizadas de cupulistas, passando a organizar o que ficou conhecido como "comitês clandestinos de fábrica".

Tais comitês, na época, tinham escassa representatividade; constituíam mais grupos de discussão e um molecular trabalho de propaganda política, que editavam boletins, faziam denúncias e procuravam estudar a história da classe operária e a teoria revolucionária do proletariado. Traziam em si um conjunto

5 Consultar a compilação documental reunida e publicada pelo professor Celso Frederico, A esquerda e o movimento operário 1964/1984 - A reconstrução. Volume III. (Belo Horizonte: Oficina de Livros, 1991). 
de concepções principescas e eram esses os princípios que lhe davam certa unidade política: defesa do socialismo, recusa das práticas conciliatórias de classe e a primazia da participação e da ação direta das bases. Havia nos grupos uma evidente simpatia pela Revolução Cubana e pela luta armada. Exceto em alguns momentos de maior mobilização (quando eram criadas coordenações para o melhor desenvolvimento de suas ações) não possuíam qualquer direção regular e verticalizada. As reuniões de seus integrantes eram realizadas nos mais diversos lugares, mas sempre em função do cumprimento de tarefas ligadas à mobilização ou organização política para movimentos concretos.

Em 1966, quando a UNE propunha o voto nulo, adotaram uma posição singular: anular os votos para deputados e senador, mas participar ativamente da campanha no âmbito municipal. Apoiou assim um candidato do MDB a prefeito, Guaçu Pitteri, e lançou candidato próprio (pela legenda de oposição) a vereador; também fez propaganda de dois outros candidatos a vereador. Todos foram eleitos!

Aproveitando-se de sua presença na Câmara Municipal e relativa influência na Prefeitura, também tentaram participar de Sociedades Amigos de Bairro e em campanhas de alfabetização de adultos. Depois de março de 1968, ou seja, depois das passeatas em protesto que foram realizadas pela morte de Edson Luís, alguns militantes de Osasco entrariam no processo de luta ideológica que se travou substancialmente em toda esquerda sobre os rumos que deveriam ser tomados pelos que lutavam contra a ditadura militar. Também lá, um dos pontos centrais do debate foi à questão da tomada do poder pela via armada.

Em 1967, a partir da Comissão da Cobrasma, com operários de outras fábricas a FNT e o grupo de Osasco organizaram uma chapa para participarem das eleições sindicais. A FNT ficou com a maioria dos cargos, mas o grupo de Osasco teve maior influência na definição do programa. Este colocou claramente a luta contra o arrocho, pelo direito de greve, pela organização de comissões de empresa, pelo reajuste trimestral de salários como reivindicações programáticas centrais; também propunha a adoção do sistema de contratação coletiva de trabalho que era, na época, considerado uma grande e desconhecida novidade.

A chapa de situação (Azul) foi encabeçada por Henos Amorina (presidente do Sindicato dos Metalúrgicos de Osasco de 1965 a 1967). Em quase todas as fábricas, os resultados acabaram revelando certo equilíbrio entre as duas chapas. A contagem dos votos dos trabalhadores da Cobrasma decidiu as eleições em favor da Chapa Verde, liderada por José Ibrahim. Mas logo depois, em virtude das posições políticas assumidas publicamente pela nova direção metalúrgica de Osasco, o sindicato esteve prestes a sofrer uma intervenção da Delegacia Regional do Trabalho (DRT), inclusive, o presidente acabou suspenso do cargo por quinze dias.

Após o fracasso do MIA, os dirigentes sindicais paulistas passaram a organizar uma "festa" para o primeiro de maio. A direção metalúrgica de Osasco foi convidada para os preparativos, o que fez articulando-se com as oposições sindicais, entidades estudantis e organizações políticas armadas para transformar 
a data comemorativa num dia de luta. Enquanto as direções pelegas convidaram autoridades e artistas para a solenidade do dia do trabalhador, a diretoria dos metalúrgicos de Osasco mobilizou suas bases, fazendo propaganda de duas palavras-de-ordem: "Minas é exemplo de luta" e "Greve contra o arrocho".

Durante o Primeiro de Maio, José Ibrahim foi muito criticado por algumas organizações políticas estudantis, tendo sido classificado até como pelego por não ter aparecido na Praça da Sé, embora o sindicato tenha fretado alguns ônibus e custeado a ida de mais de mil trabalhadores ao ato. $\mathrm{O}$ risco de uma iminente intervenção da DRT foi à razão da ausência de Ibrahim, levantada pela diretoria do sindicato e outros membros do grupo de Osasco.

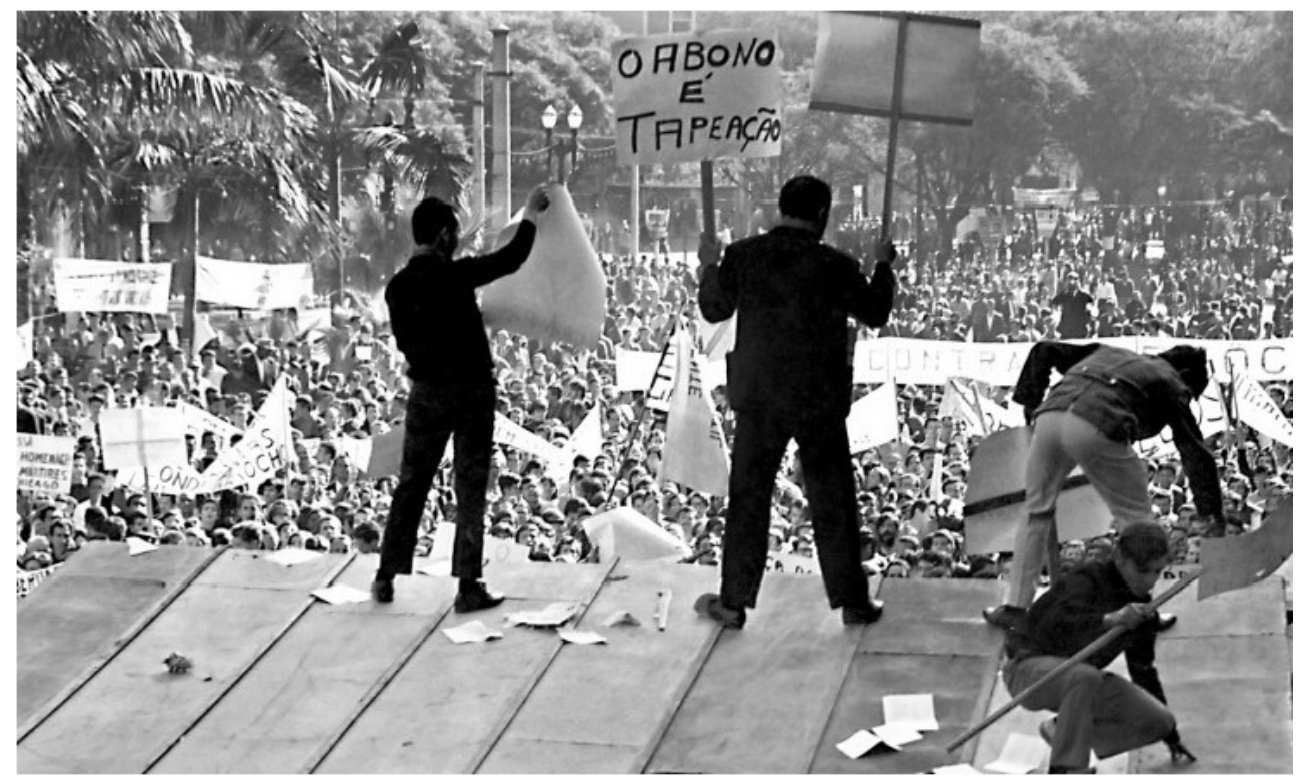

Figura 11: Manifestantes tomam o palco das autoridades e protestam durante as solenidades realizadas, na Praça da Sé (SP), no primeiro de maio em 1968.

FONTE: Acervo do autor

As correntes estudantis que hostilizavam Ibrahim acusando-o de pelego não sabiam de dois fatos que estavam em curso: uma greve estava sendo preparada secretamente pelos trabalhadores de Osasco; como também, entre os trabalhadores, julgava-se fundamental continuar participando da diretoria do sindicato para poder preparar e deflagrar esse movimento paredista. 


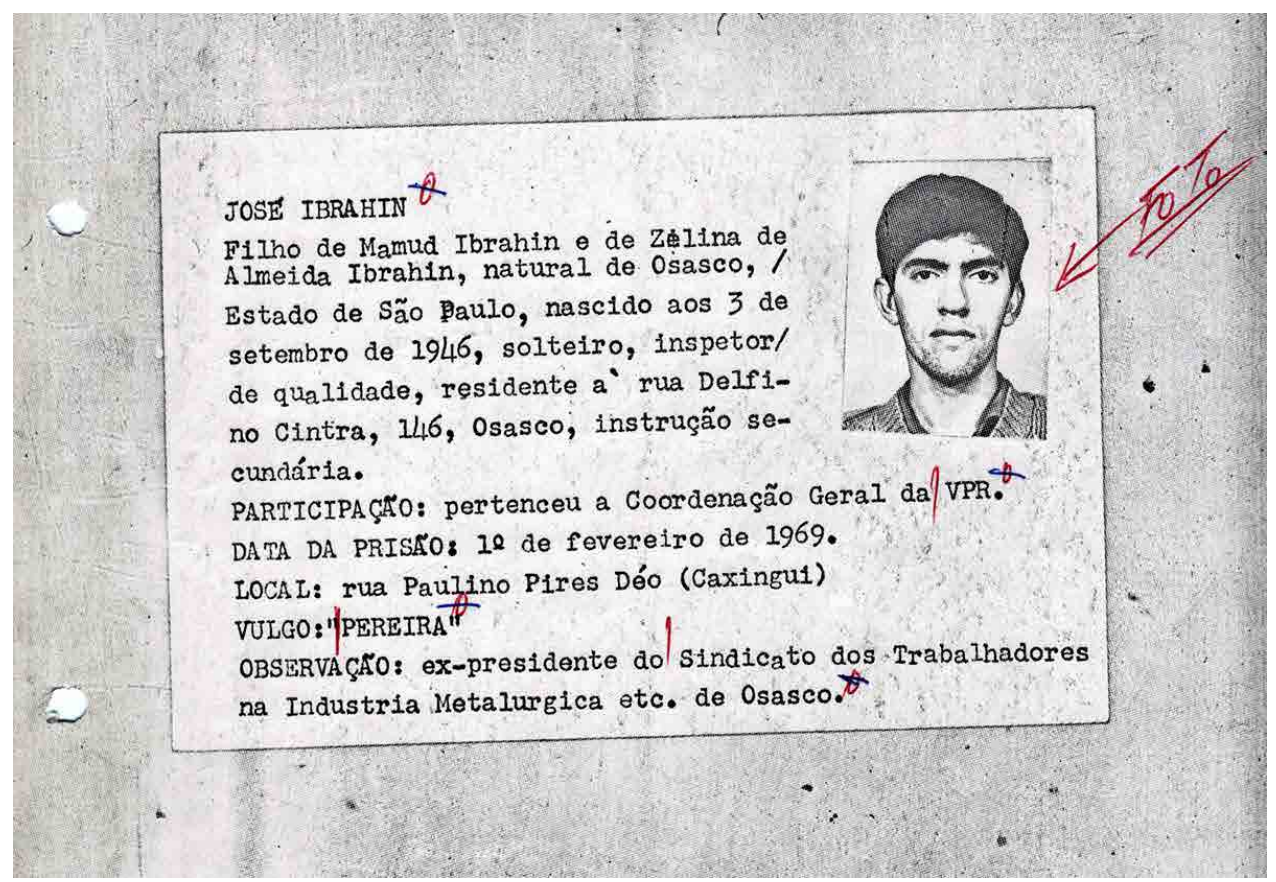

Figura 12: Ficha de José Ibrahim no Departamento de Ordem Política e Social (DOPS).

O DOPS, criado em 30 de dezembro de 1924, foi o órgão do governo brasileiro, utilizado durante o Estado Novo e, mais tarde, principalmente, na Ditadura Civil-Militar instalada, em 1964, como parte do aparato estatal repressivo e inibidor das liberdades políticas e democráticas no país.

FONTE: Acervo do autor

A greve de Contagem pegou o regime de surpresa, forçando-o a negociar e a fazer concessões. Consistiu num primeiro "furo" no arrocho, mas este se continuasse a sofrer novas afrontas acabariam comprometendo por completo a própria política econômica governamental de controle salarial. A greve de Contagem teve implicações políticas na medida em que desafiou a política econômica oficial vigente. Mas em julho, o fator surpresa já não existia mais. Só um movimento extremamente organizado poderia ser vitorioso. 


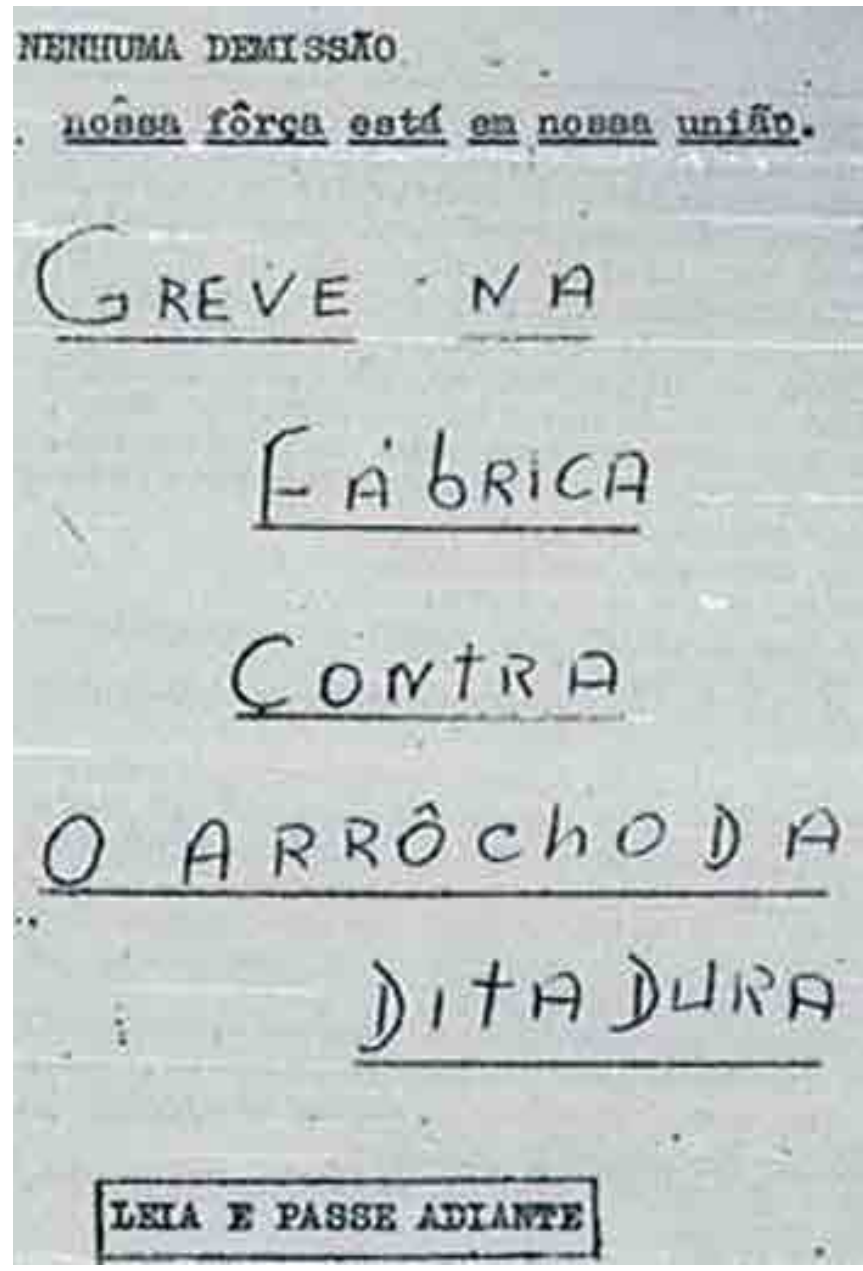

Figura 13: Panfleto operário chamando a organização da greve dos metalúrgicos de Osasco (SP) em 1968.

FONTE: Acervo do autor

No final de junho, os estudantes paulistas haviam ocupado a Faculdade de Filosofia (Maria Antonia) e havia notícias de movimentos camponeses ocorrendo em Santa Fé do Sul (São Paulo). Além disso, articulava-se a Frente Ampla com Carlos Lacerda, Jango e Juscelino, o que lançavam suspeitas de que uma hipotética cisão no seio das classes dominantes estava em franco progresso. Esses simples fatos bastaram para cegar os olhos à conjuntura política e para alentar a esperança dos que entendiam que a mera entrada do movimento operário em cena poderia alterar fundamentalmente os rumos históricos do país. Se a possibilidade de repressão quase imediata à greve era um dado quase palpável, por outro lado, havia expectativas tão grandes que se acreditava na possibilidade de, pelo menos, o movimento grevista abalarem um pouco os sólidos alicerces do regime ditatorial. 
Um enviado do delegado regional do Trabalho, o General Moacyr Gaya, foi a Osasco dialogar com Ibrahim, que como no script que vinha de Contagem, procurou isentar o sindicato da responsabilidade pela greve. $\mathrm{O}$ Coronel Passarinho imediatamente partiu para São Paulo e montou seu QG no Palácio dos Bandeirantes. No começo dessa mesma noite, a polícia interveio. Primeiro na Lonaflex, depois na Cobrasma. Mesmo diante da rápida ação repressiva do governo, no dia seguinte, outras fábricas aderiram: Braseixos, Brown Boveri e, parcialmente, a Cimaf, a Eternit e produziu um total aproximado de $10 \mathrm{mil}$ grevistas, algo impressionante e mesmo inusitado para aqueles dias marcados pela intensa repressão política e social. Depois a polícia investiu contra o sindicato, pois, já havia sido decretada a sua intervenção.

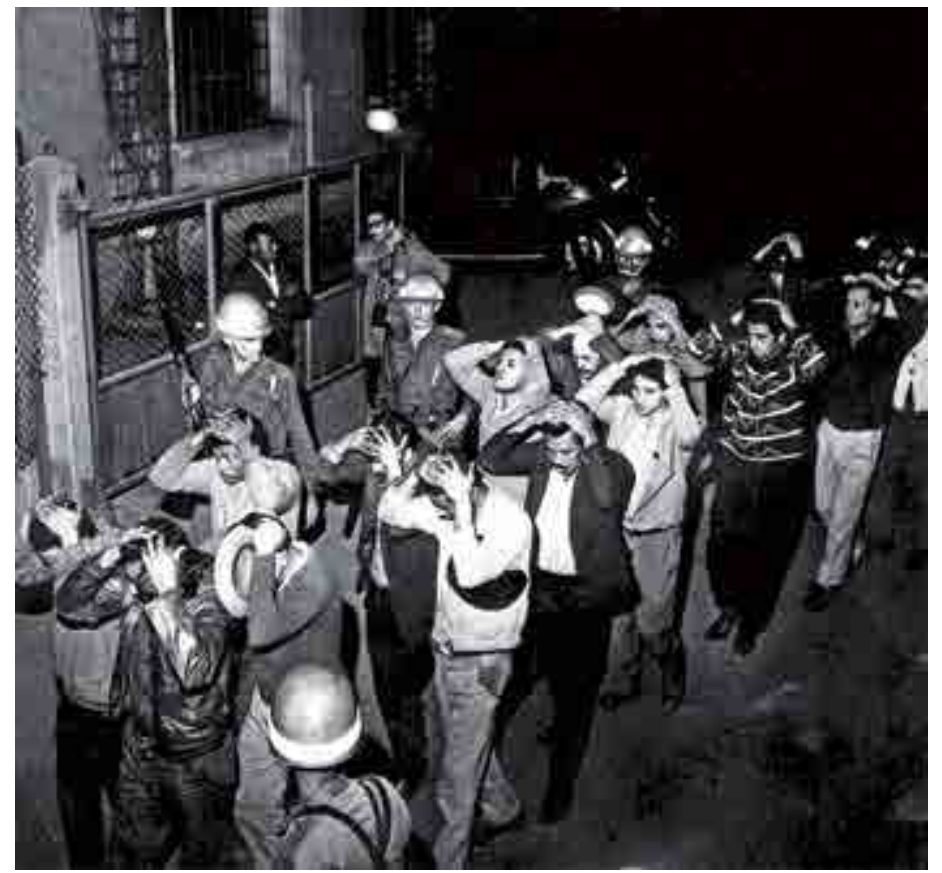

Figura 14: Registro fotográfico da prisão dos metalúrgicos de Osasco (SP) em 1968. FONTE: Acervo do autor

No primeiro dia, foram realizados cerca de 300 a 400 prisões na Cobrasma e aproximadamente 50 operários ficaram detidos; no segundo dia, ocorreram algumas prisões em igrejas e a cidade foi toda ocupada por policiais em duplas, com cachorros amedrontadores e armas de guerra em punho - a máxima governamental de que o pior inimigo era o interno mostrava-se à luz do dia.

No terceiro dia, mesmo sem um comando de greve, pois as maiorias dos seus líderes encontravam-se presos ou escondidos, o movimento continuou. Perseguidas e atuando de forma dispersiva, as lideranças tentaram conter o movimento buscando evitar um desastre ainda maior, ou mesmo uma derrota histórica e que o prostrasse de forma irremediável. Numa assembléia 
de estudantes em apoio aos grevistas, Manuel Dias do Nascimento, o Neto de Osasco, chegou a prometer "a continuação do movimento com greves de grevilhas", ou seja, paralisação um dia de uma seção, outro dia de outra e, num outro ainda seriam estimuladas as faltas dos moradores de um ou de outro bairro ao trabalho.

Após o sexto dia, as fábricas de Osasco funcionavam normalmente. Inúmeros trabalhadores foram despedidos, outros tiveram que ficar foragidos em função das buscas policiais que haviam se produzido desde o início do conflito. Tempos depois, a maior parte das empresas, para evitar problemas, acabou atendendo algumas reivindicações específicas dos operários e se chegou mesmo a oferecerem cotas variáveis de antecipação salarial.

Em Contagem e Osasco restaram núcleos organizados. Em Contagem, em outubro ocorreu uma segunda greve, que foi preparada exclusivamente a partir das organizações que atuavam na região. Só durou um dia, sendo dissolvida pela polícia e o sindicato sofreu intervenção governamental.

Em Osasco, os núcleos restantes, em setembro e início de outubro, começaram a se aglutinar para, de novo, reconstituir a oposição sindical. Entretanto, as lideranças mais expressivas já estavam mais voltadas para a vida interna de sua organização política e se preparavam para "abandonar a cidade" em troca de realizarem a cada vez mais próxima opção pela guerrilha. A dificuldade para reorganizar a oposição sindical foi ampliada ainda mais quando os líderes de Osasco foram sendo presos um a um.

O principal desdobramento político do movimento estudantil, na década de 1960, que foi o enfretamento armado ao regime militar, o levou primeiro para fora do movimento operário e, depois para a derrota armada, infortúnio que também haveria de se abater sob as principais lideranças operárias. $\mathrm{O}$ elo orgânico entre os movimentos de Osasco e Contagem e o movimento operário posterior foi precocemente abortado, mas a experiência daqueles movimentos permaneceu. Primeiro eles foram tomados como exemplos pelo regime para intimidar a classe operária, todavia eles precisam ser repensados e ajudarem à classe operária a encontrar seus próprios caminhos de organização política e sindical no Brasil.

A experiência das comissões de fábrica, de atuação nos sindicatos (ainda que atrelados), a luta contra o arrocho, pelo direito de greve realizando greves e pelo contrato coletivo de trabalho aparecem como luzes não de um relâmpago perdido num dia de céu azul, mas daquelas centelhas que iluminam os mais escuros dos caminhos.

Os acontecimentos de Osasco e Contagem não podem ser menosprezados pelos artífices de nossa história social, pois marcaram de forma substancial e com os traços da rebeldia operária os acontecimentos políticos registrados na sociedade brasileira em 1968, além do que precisam ser lembrados os que ousam nadar contra a corrente e que projetam a história como possibilidade e não como fatalidade social. 


\section{CONCLUSÃO}

A partir de 1968 a classe trabalhadora, a juventude e os movimentos sociais tiveram que viver um período de fortes limitações em suas lutas e ações cotidianas que acabariam soterradas por uma intensa e sistemática repressão estatal. As derrotas sofridas e as duras lições que foram tomadas levaram os movimentos a desenvolver suas atividades na clandestinidade. Diante das circunstâncias impostas pela repressão deflagrada pela ditadura militar, o trabalho político acabou sendo realizado silenciosa e cotidianamente no interior das fábricas e a implantação dessa perspectiva trouxe consigo elementos de "basismo" e autonomia operária, sendo fundamental para o estabelecimento dos alicerces e a expansão do chamado "novo sindicalismo" que começou a se apresentar a partir de 1977. Tais objetivos podiam então ser identificados pela trajetória política da Oposição Sindical Metalúrgica de São Paulo. ${ }^{6}$

Mas, essa não foi à regra. Diferentes agrupamentos resolveram radicalizar suas ações na luta contra a ditadura e acabou optando pela guerrilha urbana ou rural como forma de combater a ditadura militar. Esse período acabou sendo marcado por sequestros de embaixadores estrangeiros e outras personalidades, assaltos a bancos, ataques a quartéis e várias proezas, muitas vezes desesperadas, outras heróicas de jovens lutadores das liberdades democráticas e do socialismo.

Após a derrocada do movimento operário e do movimento estudantil e a ampliação do aparato repressivo do Estado, centenas de operários, trabalhadores rurais, estudantes, profissionais liberais e outros representantes das chamadas camadas médias da população, não suportando as atrocidades do regime militar, se lançaram para a ação guerrilheira como forma de luta. Estes verdadeiros revolucionários, contudo, não dispunham das mínimas condições para enfrentarem militarmente o poder do estado capitalista fortemente instalado no Brasil.

Também os movimentos sociais daqueles dias não dispunham de lideranças de massas que fossem capazes de driblar o intenso controle social que o regime exercia através da manipulação e controle dos meios de comunicação de massa; transformados que foram em educadores sociais e responsáveis pela eficiente propaganda do Brasil potência, país do futuro e da Doutrina de Segurança Nacional utilizando-se de slogans ufanistas como "Pra frente Brasil" ou, maquiavélicos, como o famigerado, "Brasil: ame-o ou deixe-o".

Naquele momento, pelas armas, não era possível vencer a ditadura militar. Mas, muitos tentaram como Lamarca o fez no Vale do Ribeira. Deu-se assim com a resistência heroica de algumas dezenas de militantes do PC do B nas matas do Araguaia dizimados por milhares soldados do exército brasileiro.

Do ponto de vista econômico, a ditadura militar se esforçou para garantir a implantação do instrumental material, energético, capacitação portuária,

6 Consultar, especialmente, a pesquisa de Hamilton A. Faria, "A experiência operária nos anos de resistência (A oposição sindical metalúrgica de São Paulo e a dinâmica do movimento operário)” (Dissertação de Mestrado, PUC-SP, 1986). 
estradas, mas também todo um aparato jurídico mais adequado à instauração e reprodução do grande capital internacional em nosso país.

Foram anos de crescimento acelerado da economia brasileira que embalados pelas políticas de controle social, do arrocho salarial, de um endividamento externo sem precedentes e da total abertura do país para o capital internacional, se chegou a crescer até $10 \%$ ao ano. Os resultados deste enganoso "Milagre brasileiro" foi à produção de um acelerado crescimento sem distribuição da riqueza socialmente produzida, que aumentou a concentração de renda, as desigualdades sociais, a criminalidade e os conflitos de classe.

Num quadro político como esse talvez não houvesse nenhum tipo de possibilidade de se organizar um poderoso movimento social, como aquele que mais tarde haveria de se constituir em torno do movimento das Diretas já, traduzindo de forma emblemática um amplo enfrentamento democrático contra as forças do regime militar. Naquele momento histórico, os diferentes agrupamentos revolucionários, ao fazerem sua opção pela luta armada, refletiam muito mais uma ação de desesperança do que uma possibilidade real de mudar os destinos do país pelas armas.

Podemos dizer que o saldo deste processo foi extremamente negativo para o desenvolvimento dos movimentos sociais e sua vanguarda foi duramente atacada. As prisões se encheram de trabalhadores e dezenas deles foram torturados e mortos pela ditadura militar.

Diante da impossibilidade de se realizar um trabalho de organização mais sistemático dentro das fábricas, uma parcela significativa da vanguarda do movimento operário que não havia aderido à guerrilha, apontou uma alternativa para o desenvolvimento de sua ação política: o questionamento e a busca de soluções para os monumentais problemas enfrentados pela população trabalhadora nos bairros das periferias das grandes cidades.

A organização e o fazer político nos arrabaldes dos grandes centros urbanos envolveu a luta por melhores condições de vida imediata e, assim, buscou construir mecanismos de auto-organização dos operários produzindo manifestações sociais das classes mais pauperizadas, possibilitando aos moradores alguns espaços de reivindicações dos seus mais elementares direitos de cidadãos, com isso gerando embriões de uma vontade coletiva popular. Por conta disso, evidentemente, é importante reconhecer que o trabalho político efetuado pela classe trabalhadora nos subúrbios das grandes cidades tem a possibilidade de apontar as contradições da sociedade capitalista e reivindicar a sua superação!

Talvez até mesmo com a mesma radicalidade dos que haviam sido produzidos nas fábricas de Osasco e Contagem, ao impulsionar as lutas populares pela regularização de loteamentos clandestinos, instalação de redes de luz e água, transportes coletivos, em defesa da escola pública etc. e, numa conjuntura nefasta como aquela produzida pelo governo militar, nos primeiros anos da década de 1970, o espaço político conquistados nos bairros das periferias das grandes 
cidades brasileiras significou, inegavelmente, um avanço político e organizativo bastante razoável.

De fato, após o estabelecimento de um governo golpista em 1964, podemos dizer que foi através de determinadas manifestações coletivas das classes populares, que atingiram certo nível de organização e coesão interna, vindo a constituir-se em movimentos sociais, que a participação popular acabou se expressado no cenário político nacional. ${ }^{7}$

A luta pelos transportes coletivos, escolas, por creches, postos sanitários e de saúde, áreas de lazer e recreação, pela moradia, pela legalização da posse da terra, etc., são alguns exemplos dessas novas formas de participação social que começaram a surgir depois das duras lições tomadas em 1968. Elas foram capazes de gerar e mesmo hoje em dia continuam gerados movimentos sociais variados, todos eles relacionados à reprodução da força de trabalho.

$\mathrm{O}$ reconhecimento do movimento em direção aos bairros não significou dizer que o trabalho político realizado dentro das fábricas havia sido totalmente abandonado. As lutas operárias continuaram inseridas no interior das unidades produtivas, mas de uma forma silenciosa e restrita. Não se tratava, naquele momento, de procurar desenvolver ações de massa, mas de propaganda circunscrita aos grupos de base, no interior das fábricas e nos bairros, com o objetivo de socializar experiências entre as oposições sindicais e sindicatos combativos e, simultaneamente, se esforçar para implantar novos grupos de trabalhadores, ligados às vanguardas, nas unidades de produção.

Paulatina e interruptamente, o movimento operário acabou construindo um novo patamar de ação de massas que em menos de dez anos, nos meados da década de 1970, já foi possível vislumbrar na forma de explosões operárias massivas e violentas contra as dificílimas condições de vida e a superexploração da força de trabalho então reinante.

Sabidamente não foram apenas as lições de 1968 que possibilitaram o desenvolvimento das lutas populares nos bairros da periferia, através dos chamados novos movimentos sociais urbanos. Existem muitos outros fatores e dentre eles podemos mencionar: a) a existência de associações de moradores, b) os cursos de alfabetização de adultos que eram impulsionados pelas idéias e propostas de Paulo Freire, c) cursos técnicos e profissionais, d) movimentos patrocinados pela Igreja Católica, e) comunidades eclesiais de base etc. Esses movimentos abriram um espaço importante e necessário para a implantação e consolidação do trabalho políticos nos mais distantes subúrbios das grandes cidades e não podem deixar de serem mencionados quando buscamos entender o lento processo de construção da democracia no Brasil.

Em nosso país esse tipo de luta possibilitou a emergência de alguns movimentos sociais urbanos de expressão significativa: o movimento pela Anistia em 1978-1979 e o Movimento contra a Carestia que começou a se tornar mais visível a partir de 1977. O primeiro embora tenha sido liderado por segmentos

7 Sobre essa temática, conferir, especialmente, a obra de Maria da Glória Marcondes Gohn, A força da periferia: a luta das mulheres por creches em São Paulo. (Petrópolis: Vozes, 1985). 
específicos da população brasileira, expressou uma luta que era de toda a nação, contra o arbítrio e o autoritarismo vigentes.

Outro elemento político importante a destacar neste movimento foi o papel articulador que ele representou, para as forças democráticas em geral e para os movimentos populares em particular. Com a decretação da Anistia o movimento prosseguiu através da constituição dos Centros de Defesa dos Direitos Humanos em praticamente todos os estados do país e a sua presença política é de suma importância na reconstrução da memória e da história de incontáveis cidadãos que viveram com paixão e intensidade o ano de 1968 na sociedade brasileira.

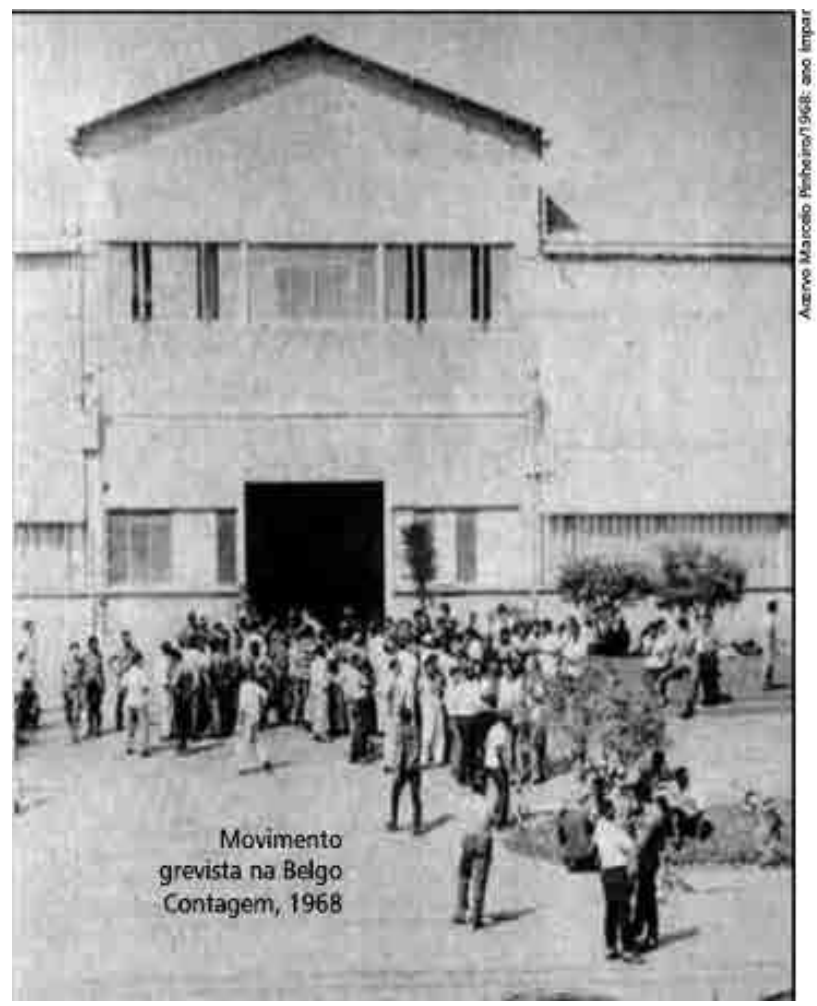

Figura 15: Manifestação dos operários metalúrgicos em greve na cidade de Contagem (MG) em 1968.

FONTE: Acervo do autor.

\section{FONTES 8}

Alves, Maria Helena Moreira. Estado e oposição no Brasil (1964-1984). Petrópolis: Vozes, 1989.

8 Nota do autor. A Revista Historia de la Educación Latinoamericana (Rhela), em seu número 11, volume 28, correspondente ao segundo semestre de 2008, publicou uma excelente coletânea de artigos, versando sobre a importância histórica do movimento estudantil latino americano e a influência política do Maio de 1968, organizados pela professora María Cristina Vera de Flach, da Universidad de Córdoba (Argentina) e membro do Grupo de investigación Historia y prospectiva de la Universidad 
Antunes, Ricardo. O que é sindicalismo. São Paulo: Brasiliense, 1986.

Bauer, Carlos. Contribuição para a história dos trabalhadores brasileiros. Volume II. A hegemonia vermelha. São Paulo: Edições Pulsar, 1995.

Benjamin, W. Obras escolhidas. Magia e técnica, arte e cultura. São Paulo: Brasiliense, 1985.

Faria, Hamilton A. "A experiência operária nos anos de resistência (A oposição sindical metalúrgica de São Paulo e a dinâmica do movimento operário)". Dissertação de Mestrado, PUC-SP, 1986.

Fernandes, Florestan. A ditadura em questão. São Paulo: T.A. Queiroz Editor, 1982.

Filho, Daniel Aarão Reis. A revolução faltou ao encontro: os comunistas no Brasil. São Paulo: Brasiliense/ MCT-CNPq, 1990.

Frederico, Celso. A esquerda e o movimento operário - 1964/1984 - A reconstrução. Volume III. Belo Horizonte: Oficina de Livros, 1991.

Gohn, Maria da Glória Marcondes. A força da periferia: a luta das mulheres por creches em São Paulo. Petrópolis: Vozes, 1985.

Gorender, Jacob. Combate nas trevas. São Paulo: Ática, 1987.

Ianni, O. A ditadura do grande capital. São Paulo: Brasiliense, 1981.

Ibrahim, José y José Barreto Campos. "Manifesto de balanço da greve de julho". Em A esquerda e o movimento operário: 1964/1984. Volume I. A resistência à resistência: 1964/1971, editado pelo Celso Frederico. São Paulo: Novos Rumos, 1987.

Simoes, Carlos. A lei do arrocho: trabalho, previdência e sindicatos no regime militar - 1964/1984. Petrópolis: Vozes, 1986.

Weffort, Francisco C. Participação e conflito industrial: Contagem e Osasco - 1968. São Paulo: Cebrap, caderno 5, 1972.

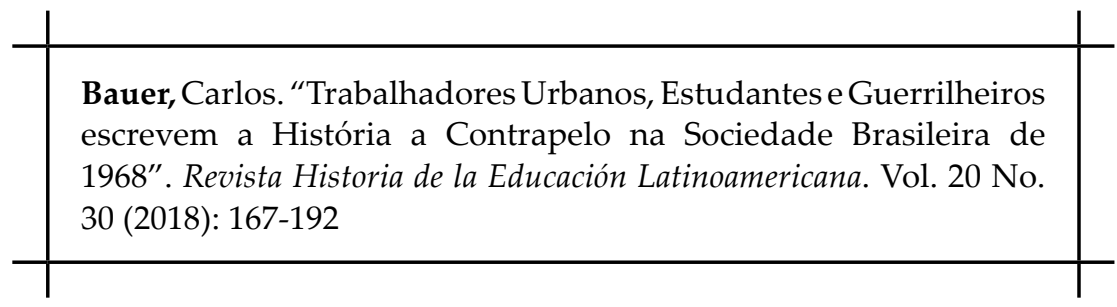

Latinoamericana (HISULA), no qual foram reunidos os seguintes articulistas e seus manuscritos: Javier Ocampo Lopez, Maestro Germán Arciniegas el educador, ensayista, culturólogo e ideólogo de los movimientos estudiantiles en Colombia; Hugo E. Biagini, La cultura de la resistencia juvenil y el proceso emancipador; John Jaime Correa Ramírez, Contra la despolitización de la memoria. Entrevista con Carlos Antonio Aguirre Rojas, A propósito de los 40 años de mayo del 68; José Rubens Lima Jardilino, Os frutos de maio: resenha histórica do movimento estudantil na América latina no inicio do século XX; Jesús Márquez Carrillo e Paz Diéguez Delgadillo, Política, universidad y sociedad en Puebla. El ascenso del Partido Comunista Mexicano en la UAP, 1970-1972; Silene de Moraes Freire, Movimento estudantil no Brasil: lutas passadas, desafios presentes; Dora Piñeres De La Ossa, Relación universidad y sociedad, prensa y política en los movimientos estudiantiles de los años cuarenta en la Universidad de Cartagena; Norma Dolores Riquelme, Conformación de los espacios de poder en el Gobierno de la Universidad Nacional de Córdoba (Argentina) a mediados del siglo XX; José Eustáquio Romão, Os frutos de maio de 1968 - O Grito dos Silenciados; Sergio Arturo Sánchez Parra, Violencia política en Sinaloa: El caso de los "Enfermos" 1972-1978 (Los lugares y medios para la radicalización) e Luis Fernando Villafuerte Valdés, Una metodología interpretativa para el estudio de los movimientos sociales. Enmarcamientos y cultura. Una visión desde México.

Os artigos acima citados podem ser acessados, livremente, em http://revistas.uptc.edu.co/revistas/index.php/historia_educacion_ latinamerican/issue/view/129

Também versando sobre essa temática, Rhela, em seu Vol. 19 No. 28, de janeiro a junho de 2017, organizados pelo professor Álvaro Acevedo Tarazona, da Universidad Industrial de Santander (Colômbia), trouxe a publicação dos seguintes artigos: Movimiento estudiantil de Córdoba y su influencia en Honduras, de Orlando David Murillo Lizardo; ¿Jóvenes e indignados? La movilización social colombiana en el año 2011, de Álvaro Acevedo Tarazona e Andrés David Correa Lugos; Constantes en los movimientos estudiantiles latinoamericanos: Aproximación a partir del caso chileno de 2011, de Andrés Donoso Romo e Protesta y movilización estudiantil en la Universidad Industrial de Santander: la oportunidad política, de autoria de Raquel Méndez Villamizar, Johana Linares García e Hector Mauricio Rojas Betancur.

Os manuscritos podem ser consultados, livremente, em

http://revistas.uptc.edu.co/revistas/index.php/historia_educacion_latinamerican/issue/view/468 